\title{
The Effect of Using Cartoon Story Maker (CSM) Software on Students' Speaking Ability at SMA N 1 Solok Selatan
}

\author{
Wiwik Rince Jelita ${ }^{1}$, Mukhaiyar ${ }^{2}$, and Desvalini Anwar ${ }^{3}$ \\ IUniversitas Negeri Padang, Padang, Indonesiawiwik1707@gmail.com \\ ${ }^{2}$ Universitas Negeri Padang, Padang, Indonesia mukhaiyar@yahoo.co.id \\ ${ }^{3}$ Universitas Negeri Padang, Padang, Indonesia desvalinianwar@yahoo.co.id
}

\begin{abstract}
This research is aimed at finding out the influence of using Cartoon Story Maker (CSM) software on students' speaking ability. Related to the aim of the research, an experimental method is carried out in SMA N 1 Solok Selatan at grade tenth. The population was all the tenth grade students of social program in 2018/2019 academic year. Two out of three classes consisting of 30 students from each were taken as the sample by applying cluster random sampling. They were class X IS 3 as the experimental group and class X IS 2 as the control group. Before giving the treatment, both of the groups were given pre-test to see the students' speaking ability before they had the treatment. For the treatment, the experimental group was learning speaking using Cartoon Story Maker (CSM) software media, while the control group was learning speaking using pictorial media. After conducting the treatment, a post-test of speaking ability was administered, then the participants' achievement in both tests were compared. The instruments of this research were questionnaire and speaking test. The result of this research found that there was a significant effect in students' speaking ability using Cartoon Story Maker (CSM) software. The students using Cartoon Story Maker (CSM) software showed higher scores than those who did not. They speak more using Cartoon Story Maker (CSM) software, therefore it improved their speaking ability. The result from questionnaire also illustrated that most of the students in the experimental group considered learning speaking using Cartoon Story Maker (CSM) software is useful and helpful. In conclusion, using Cartoon Story Maker (CSM) software contributes to the achievement of students' speaking ability in SMA N 1 Solok Selatan. Therefore, it is recommended that teachers apply Cartoon Story Maker (CSM) software in teaching speaking.
\end{abstract}

Keywords: Cartoon Story Maker (CSM) software, speaking ability

\section{INTRODUCTION}

As an international language, English is taught in almost all levels of education in the world including Indonesia. People realize that the main purpose of learning a foreign language is to use it for communication both in oral or written form. The data revealed by British Council (2013) shows that the number of English speakers have reached 1.75 billion people or about a quarter of world population. This large number is caused by the existence of English language in almost all aspects of life.

One of the ways to communicate is through speaking. Students have to master this skill as it is a tool to assess knowledge. As one of the language skills, speaking must be mastered by foreign language learners to communicate in the target language. Learners are often considered successful if they can speak or communicate in the foreign language verbally (Richard, 2002) If they can not speak English, they are often assumed unable to communicate in foreign language. Thus, it can be understood why speaking skill should be given special attention.

Based on Curriculum 2013, the objective of English teaching is to enable students to communicate in English. They have to understand and produce texts in oral and written form which is realized in four language skills; listening, speaking, reading and writing. These language skills would be used to respond or create discourse in society. For this reason, English subject in the school is oriented to develop those skills in order that students have ability to communicate in English at certain literacy levels. Junior High School students are expected to reach functional level and Senior High School students are to reach the informational level.

Moreover, the basic competence of teaching speaking for Senior High School students is to enable students to express the meaning of interpersonal and transactional function in various interactions and monologue spoken text, especially in descriptive, recount, 
narrative, analytical exposition, explanation, report, news item, and procedure (Permendiknas No.21 tahun 2016). For recount text, the students are expected to tell about events by using monologue and transaction text. Monologue is a kind of report or speech. Transaction is to tell events in conversation. It involves at least two people.

On the other hand, it cannot be neglected that speaking is not an easy task. Teaching speaking needs proper material, method and media. Media have important role in teaching speaking because they help to accelerate interaction between teacher and students. Kabapinar (2005) states that medium is a tool to deliver the message to stimulate mind, feeling, attention and students' interest for studying. There are many researchers showing the effectiveness of media for teaching speaking like slide, video, film, picture, game, cards, story telling pieces, puppets, and other.

Based on the researcher's observation and interview with English teachers of SMA N 1 Solok Selatan, it was found that there were many teachers who did not use media in teaching speaking. They seldom used media because of some reasons. First, they have limited time to prepare the media. Second, it is difficult to create or adapt appropriate media for students. Then, the syllabus they teach is tightly structured to allow for media materials to be brought into the classroom. Last, there is no fund for media development and others. As a result, teachers only use textbook in teaching speaking.

Recount text is one of texts that should be taught in Senior High School according to the syllabus of Curriculum 2013 (Permendiknas No. 24 tahun 2016). This material is taught for the first grade students of Senior High School. At SMA N 1 Solok Selatan, students' speaking ability for social class is low, especially for recount text. The objective of teaching recount text is the students are able to express meaning in simple short monologue in recount form. In other word they are able to tell an event in simple ways. In teaching recount text, the teacher usually writes the list of vocabularies that relate to the events, for example rememberance, hero, soldier, and other. Then, the teacher gives example by telling an events. However, if the students are asked to tell another events, they cannot. They tend to see the paper which is consisted of the events that theu want to tell. They think that it is not interesting activity. They just tell or retell the events. It can be concluded that the objective of curriculum is not achieved yet.

Based on the phenomena above the researcher assumes that lack of media in teaching speaking is one of the factors that cause the problems. In the teaching and learning process, media support the effectiveness of teaching. Furthermore, media bring the meaning of the language for students. Language has lack meaning when it is introduced with its translation. On the other hand, it will be more meaningful if students acquire the language with its object. There are several media that can be used for teaching. One of them is pictorial media. Picture is one of good media for teaching recount text. It helps students in telling an experience or event. When the students are asked to tell about their holiday, the students will prepare some pictures that they got from their holiday. Then, they will tell it to their friends and teachers.

Beside pictorial media, Cartoon Story Maker (CSM) software is also an effective media for teaching speaking. This software can be used easily as it is already completed with some characters, background, and some other features such as: captions, balloons, the choice of publishing, etc. This is free and downloadable software and can be used in computer friendly, which means that to download it, we do not need a huge memory or a fancy computer specification. The extension of the file when it is published is also friendly user. Its extension is html and pdf form, so this software can be used in all computer users. As a supplementary teaching and learning material, there are some concepts of designing cartoon in educational field. The first concept comes from Kabapinar (2005). Based on his study to some students in a science class, as a teaching and learning material, the effective cartoon can be a tool to find out students' ideas without being affected by others. It can provide a purpose for practical work, and fix students' misconception. Another concept is stated by Kabapinar (2005). He claims that in order for Cartoon Story Maker (CSM) to be effective as a teaching material, the following points must be fulfilled. First, in the cartoon, the amount of the texts must be as minimal as possible, the cartoon presents a real life situation, and the cartoon's content should be credible for teaching and learning purposes.

Considering cartoon as a teaching and learning material, Bell and Gower as cited in Tomlinson (2003) states that the author needs to compromise in designing a teaching and learning material, that the material should meet the teachers and learners' practical need and it should match the realities of publishing material. In addition, Tomlinson (2003) views the course book as one of the materials designed to capitalize on teachers' capacity for creativity. Next, Fauzan (2014b) states that teaching materials should be developed to make the students get the ability to communicate in English in academic and non academic situations. Then, Fauzan (2014c) also states that one of the important keys of the improvement of the students' English ability is an appropriate teaching material. So there are other two main points to be considered in designing a cartoon as a teaching material. The first, the teacher may use cartoon because it is possible to be created, published, and used by teacher and/or students; and the second, teachers' creativity can be supported by cartoon in teaching. In this research, the researcher uses Cartoon Story Maker (CSM) software for teaching speaking, especially in recount text. Therefore, the researcher is interested in conducting the research in order to test the effect of using cartoon story maker (CSM) software on students' speaking ability for Recount Text at SMA N 1 Solok Selatan.

\section{METHOD}

The design of this research was a quasi experimental research. Experimental is a form of quantitative research. It compared the result of two 
researches group. The researchers manipulated the independent variable then control other variable and observed the effect of dependent variable. According to Gay (2000) experimental research is the only type of research that can test hypotheses to establish cause and effect relationships. In experimental study, the researcher manipulates at least one independent variable, controls the relevant variables, and observes the effect on one or more dependent variables.

The population of this research was the first grade students of SMA N 1 Solok Selatan in social class for academic year of 2018/2019. There were 91 students which classified into three classes. They were X IS 1 (31 students), X IS 2 (30 students) and X IS 3 (30 students). The researcher used cluster random sampling to select the sample. The processes were: (1) the three classes were selected randomly, the researcher prepared three small pieces of papers which were written the name of each class and rolled it; (2) She placed the small roller papers into a glass and shoke them; (3) She took only two papers, the first small roller paper was the experimental group and the second one was the control group. Others did not assign in this research. This research was conducted for two months.

This researcher used speaking test as instrument or tool to collect the data. The speaking test was given to test the students' speaking ability. The test was telling a recount text. The researcher gave the oral test to the students to measure their speaking skill after getting the treatment. The test given to the students both in experimental and control class was the same. The topic of test was about the historical events. The test was conducted in duration 3-7 minutes. During the test, the teacher directly gave some scores based on the rubric she prepared for each student.

In analyzing the data, the researcher used quantitative data analysis. According to Best and Kahn (1995: 26), quantitative research uses quantitative methods to describe what is, describing, recording, analyzing, and interpreting conditions that exist. It involves some type of comparison or contrast and attempts to discover relationships between exiting no manipulated variables. Some form statistical analysis is used to describe the result of the study.

Statistical procedures are steps that used statistically to analyze the students' achievement. To interpret the students' result, the researcher used statistical procedure using t-test:

$S x 1 . x 2=\sqrt{\frac{\sum \times 12+\Sigma \times 22}{\mathrm{n} 1+\mathrm{n} 2-2}} \frac{1}{n 1}+\left[\frac{1}{21}\right]$

$S \times 1 . x 2=$ the standard error of the difference between two means

$\Sigma x 12=$ the sum of the squared deviation scores of group 1

$\Sigma \times 22=$ the sum of the squared deviation scores of group 2

$n 1 \quad=$ the number of cases in group 1

$n 2 \quad=$ the number of cases in group 2

$$
\mathrm{t}=\frac{\mathrm{M} 1-\mathrm{M} 2}{\mathrm{~S} \times 1-\mathrm{x} 2}
$$

where:

$M 1-M 2 \quad=$ the observed difference between two means

Sx 1. $x 2=$ the standard error of the difference between two means (expected difference between the two means when the null hypothesis is true)

(Arikunto, 2006: 311)

\section{RESULTS AND DISCUSSION} Results

This research was conducted at SMA N 1 Solok Selatan. It addresses on Jl. Raya Rawang Muaralabuh, Solok Selatan, phone : 075570028. This research conducted on February - April 2019 academic year 2018/2019. The researcher took two classes. They were class X IS 2 and X IS 3. Class X IS 2 was as a control group and $\mathrm{X}$ IS 3 was as an experimental group. Each class consisted of 30 students.

In the research, Firstly, the researcher gave to both of classes the pre-test. After that, the researcher found out the student's score as the result of the pre-test. Secondly, the researcher divided two classes by simple random sampling. They were class X IS 2 as a control group and class X IS 3 as an experimental group. Third, the researcher explained about the use of Cartoon Story Maker (CSM) Software to the students of class X IS 3 as an experimental class. Fourth, the students of class X IS 3 practiced Recount Text materials using Cartoon Story Maker (CSM) Software. Fifth, the students of class X IS 3 told their Recount Text using Cartoon Story Maker (CSM) Software in front of the class. The last, the researcher gave the post-test in class X IS 2 as a control group and class X IS 3 as an experimental group. After that, the researcher could find out the result of the treatment whether successfully or not. The data which were analyzed in this research are the result of the test. The score of students in an experimental group were compared with the score of the students of a control group.

The result of the research indicated that there was significant different students' speaking ability using Cartoon Story Maker (CSM) Software and students' speaking abilityusing other media (Pictorial Media). It can be seen from the students score after conducted pre-test and post-test. The average score pre-test of class X IS 2 as a control class was 49,53 and the post-test became 55,31. The average score pre-test of class X IS 3 as an experimental class was 48,59 and after implemented Cartoon Story Maker (CSM) Software became 64,06.

Based on the computation of t-test showed that $\mathrm{t} 0=10,67$ while $t$ for the significant level was $5 \%(\alpha=0,05)$ with degree of freedom $(\mathrm{df})=62$ is 2,02 . It could be seen from $\mathrm{t} 0$ and $\mathrm{tt}$, in which $\mathrm{t} 0$ was higher than $\mathrm{tt}(10,67>2.02)$. Group of students who taught using Cartoon Story Maker 
(CSM) Software (experimental group) got higher achievement than those who taught using other media (Pictorial Media) (control group). This was known from the different score. The mean score of the two groups showed that the experimental group pre-test was 48,15 become 62,03 in the post-test and the control group pretest was 47,51 become 53,81 in the post-test. It can be seen from the following figure:

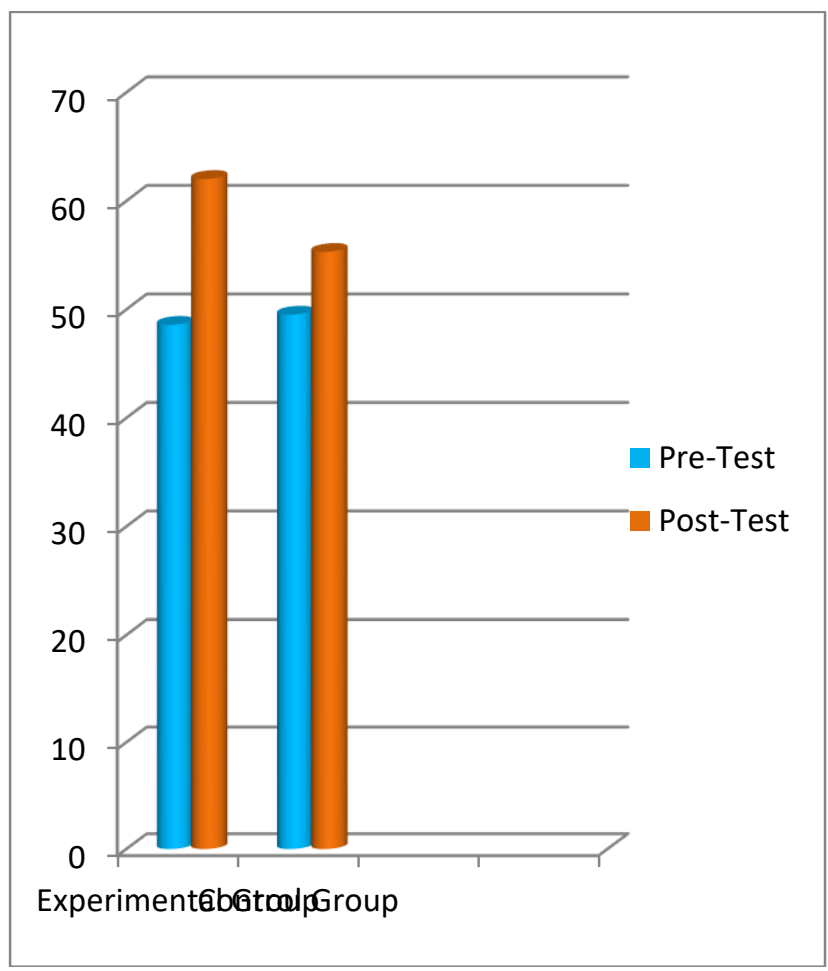

Figure 1. The mean score of the two groups

So, it could be concluded that students' speaking ability using Cartoon Story Maker (CSM) Software was better than students' speaking ability using other media (Pictorial Media). In other word, the use of Cartoon Story Maker (CSM) Software in teaching and learning speaking skills made the student to learn how to speak more intensively and actively

\section{DISCUSSION}

The result of the study showed that the group of teaching and learning speaking skill using Cartoon Story Maker (CSM) Software was better than teaching and learning speaking skill using other media (Pictorial Media). The mean of pre-test score of control group was 47,51 and the mean of pre-test score of an experimental group was 48,15 . After both of group were gave different treatment which was an experimental group teaching learning speaking skill using Cartoon Story Maker (CSM) Software and a control group using other media (Pictorial Media), in the end of teaching-learning process was found out that there was different result in student's speaking ability. The mean of post test score of a control group was
53,81 , and the mean of post-test of an experimental group was 62,03 .

The aim of using media such as Cartoon Story Maker (CSM) Software was to get learners to used the language they were learning to interact in realistic and meaningful ways, which involving exchanges of information. It was in line with the goal of learning a language which usually to enable learners to take part in exchanges of information. As we know that some teaching methods which emphasizes the learning of language systems as a goal failed to gave learners an opportunity to practice to speak in class that is why there were some students who had learn a language unable to speak even a sentence.

During the research, it was found that an experimental class who had lower score in pre-test than a control class could achieved higher score than a control class in post-test, it was because the students in an experimental class practiced to speak more than the students in a control class. Moreover, the students in a control class felt bored during the teaching and learning process, different with students in an experimental class who seemed enthusiastic during the teaching and learning process since they were exposed with an interesting mediasuch as Cartoon Story Maker (CSM) Software. Therefore, it could be seen that the students in a control class had a lower concentration than the students in an experimental class. Even it was found that in an experimental class, the students' memory toward the material was better than the students in a control class who found forget the material easily after the learning process. Cartoon Story Maker (CSM) Software which applied in an experimental class gave students opportunity to practice speaking English in class. Moreover, it could increase the students' motivation in learning English since they felt their purpose of learning English can be achieved by using interesting media such as Cartoon Story Maker (CSM) Software.

The result of the research shows that teaching and learning speaking using Cartoon Story Maker (CSM) Software increases the students' speaking ability. It means that teaching and learning speaking using Cartoon Story Maker (CSM) Software is appropriate to be applied for teaching and learning speaking at tenth grade students of social program of SMA N 1 Solok Selatan. It is a media that can help students to use English to communicate in a real life by asking the students to tell the story using moden technology so that they can enjoy studying speaking. By using Cartoon Story Maker (CSM) Software, students are actively involved in teaching learning process and they are trained to use the target language to communicate. Also, they can apply the modern technology using media in their speaking skill to make them interested to study and practice their speaking ability. It might be concluded that by implementing Cartoon Story Maker (CSM) Software in learning speaking, it can improve the students speaking ability than the students who are not exposed with this media or other media (Pictorial Media). 


\section{CONCLUSIONS}

Based on the result of the research, the researcher concludes that:

1. There was a significant difference between group of the students who taught using Cartoon Story Maker (CSM) Software (experimental group) and who taught using other media (Pictorial Media) (control group). It could be seen from t0 and tt, in which t0 was higher than $t \mathrm{tt}(\mathrm{tt}(10,67>2.02)$. Group of students who taught using Cartoon Story Maker (CSM) Software (experimental group) got higher speaking ability than those who taught using other media (Pictorial Media) (control group). This was known from the different score. The mean score of the two groups showed that the experimental group got 62,03 while in the control group got 53,81.

2. Teaching and learning speaking skill using Cartoon Story Maker (CSM) Software made the student to learn how to speak more intensively and actively. The students had problem with speaking because they did not know how to speak, and the media is not interesting for them. Using Cartoon Story Maker (CSM) Software, teacher acted as a guide who helped the students to speak well.

The result of the research proves that teaching and learning speaking using Cartoon Story Maker (CSM) Software is more effective than teaching and learning speaking using other media (Pictorial Media). It is able to increase the students' speaking ability especially for the tentth grade students of social program of SMA N 1 Solok Selatan in 2018/2019 academic years.

In this research, the researcher would like to give some suggestions as follows:

1. To the English teacher

Teaching learning English is not difficult. The teacher should use various methods and media in teaching in order to make the students interested in lesson subject. Speaking is one of English skill that has more complicated than the other skill. The teacher should be able to choose and use appropriate method and media in teaching and learning speaking. Knowing that the students' ability in teaching and learning speaking using Cartoon Story Maker (CSM) Software is better than teaching and learning speaking using other media (Pictorial Media), the researcher would like to suggest that Cartoon Story Maker (CSM) Software must be considered to be used.

\section{To the Students}

The students as learners must be able to master four language skills, they are reading, speaking, writing, and listening. Speaking looks like a simple thing to do but actually it has many difficulties if the students do not know the way to speak orally. To increase the student's speaking skill, they have to learn speaking by practice and practice. From this research, students are suggested to applyCartoon Story Maker (CSM) Software in speaking so they will be more skillful in speaking.

\section{To the Other Researchers}

The researcher hopes the result of this study will be useful and contribute some valuable thing to the researcher and the other researcher. For the researches who intend to conduct the research more detail about the effect of using Cartoon Story Maker (CSM) Software on students' speaking ability, the researcher hopes that the research findings can be used as a starting point of the future researchers who have the same problems and this research can be utilized as reference.

\section{ACKNOWLEDGMENTS}

In accomplishing this thesis, there were great people who have contributed to this research. My deepest appreciation goes to my advisors, Prof. Dr. Mukhaiyar, M.Pd and Desvalini Anwar, S.S, M.Hum, Ph.D who have given valuable ideas, guidance, correction, suggestion, beneficial opinion and encouragement in the process of accomplishing this thesis. It is a pleasure to pay tribute also to my contributors, Dr. Hamzah, M.A, M.M and Dr. Havid Ardi,S.Pd, M.Hum, for their suggestions, comments, time, contribution of thoughts and ideas toward the development and accomplishment of this thesis.

\section{REFERENCES}

[1] Arikunto, Suharsimi. 2006. Prosedure Penelitian: Suatu Pendekatan Praktek. Jakarta: PT Rineka Cipta.

[2] British Council. 2013. The English Effect. www.britishcouncil.org.

[3] Brown, Douglas. 2001 Teaching by Principles: An Interactive Approach to Language Pedagogy. Longman.

[4] Cameron, Lynne. 2001. Teaching Language to Young Learners. Cambridge: Cambridge University Press.

[5] Elvinna Manurung, Jenny. 2015. Using Cartoon Story Maker 1.1 in Developing Writing English Skills in EYL Classrooms. (pp. 39 - 46). Palembang: Jurnal Didascein Bahasa November 2015 Volume 1 No. 1.

[6] Fauzan, U. 2014b. Developing EFL Speaking Materials for the Second Semester Students of STAIN Samarinda (pp. 861-864). Surakarta: Proceedings of 61th TEFLIN International Conference.

[7] Fauzan, U. 2014c. The Use of Improvisation Technique to Improve the Speaking Ability of EFL Students. DINAMIKA ILMU, 14(2).

[8] Kabapinar, F. 2005. Effectiveness of Teaching via Concept Cartoon from the Point of View of Constructivist Approach. Kuram ve Uygulamada Exitim Bilimleri / Educational Sciences: Theory \& Practice, 5(1), 135-146.

[9] Mina, Nurawati dan Sulistini Dwi Putranti. 2015. Designing Cartoon as Supplementary Material for 
English Structure Subject. (pp. 115 - 136). Jakarta: Dinamika Ilmu Volume 15 No. 1.

[10]Nunan, David . 2003. Designing Tasks for the Communicative Classroom. Cambridge: Cambridge University Press.

[11] Richards, Jack C. \& Willy A. 2002. Methodology in Language Teaching. New York: Cambridge University Press.

[12] Shumin, Kang. 2002. Factors to Consider: Developing Adult EFL Students' Speaking Abilities. English Teaching Forum Journal, Vol 35, No 3, July-September 1997, retrieved on May 24th 2011.

[13] Tomlinson, B. (Ed.) 2003. Developing Material for Language Teaching. Continuum: Bloomsbury Publishing. 